Supporting information for:

\title{
Competitive C-H Bond Activation and $\beta$-Hydride Elimination at Platinum(II)
}

\author{
Susan M. Kloek and Karen I. Goldberg*
}

Department of Chemistry

Box 351700, University of Washington, Seattle, Washington 98195-1700 


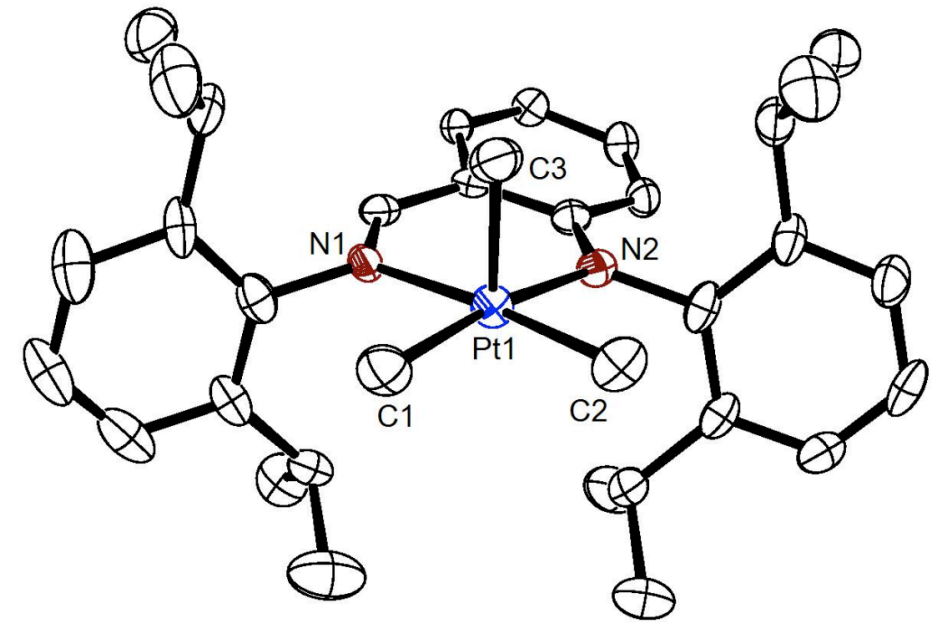

Figure S1. ORTEP drawing of $\mathbf{1 b}$. Thermal ellipsoids at 50\% probability. Select bond distances $(\AA)$ and angles (deg): Pt1-N1 = 2.131(4), Pt1-N2 = 2.128(4), Pt1-C1 = 2.056(5), Pt1-C2 = 2.047(5), Pt1-C3 = 2.016(5), C1-Pt1-C3 = 87.6(2), C2-Pt1-C3 = 87.3(2), N1-Pt1-C3 = 96.5(2), N2-Pt1-C3 = 100.3(2), N1-Pt1-N2 = 87.9(2).

Table S1. Crystallographic Data

\begin{tabular}{|c|c|c|}
\hline & 1b & $2 \mathbf{b}$ \\
\hline Empirical formula & $\mathrm{C} 34 \mathrm{H} 48 \mathrm{~N} 2 \mathrm{Pt}$ & $\mathrm{C} 38 \mathrm{H} 46 \mathrm{~N} 2 \mathrm{Pt}$ \\
\hline FW & 679.83 & 725.86 \\
\hline $\mathrm{T}(\mathrm{K})$ & $130(2)$ & $130(2)$ \\
\hline Wavelength $(\AA ̊)$ & 0.71073 & 0.71073 \\
\hline crystal description & needle & plate \\
\hline space group & P 21/c & $\mathrm{P} 2 / \mathrm{c}$ \\
\hline unit cell dimensions & $a=16.4080(5)$ & $\mathrm{a}=15.1370(7)$ \\
\hline & $b=11.5010(5)$ & $\mathrm{b}=9.2350(2)$ \\
\hline & $c=17.1640(6)$ & $\mathrm{c}=23.2250(10)$ \\
\hline & $\alpha=90^{\circ}$ & $\alpha=90^{\circ}$ \\
\hline & $\beta=107.080(2)^{\mathrm{o}}$ & $\beta=91.0500(14)^{\mathrm{o}}$ \\
\hline & $\gamma=90^{\circ}$ & $\gamma=90^{\circ}$ \\
\hline $\mathrm{V}\left(\AA^{3}\right)$ & $3096.1(2)$ & $3246.1(2)$ \\
\hline $\mathrm{Z}, \rho\left(\mathrm{mg} / \mathrm{m}^{3}\right)$ & $4,1.458$ & $4,1.485$ \\
\hline$\mu\left(\mathrm{mm}^{-1}\right)$ & 4.555 & 4.350 \\
\hline$F(000)$ & 1376 & 1464 \\
\hline crystal size & $0.10 \times 0.04 \times 0.04 \mathrm{~mm}$ & $0.24 \times 0.24 \times 0.09$ \\
\hline reflections for indexing & 832 & 127 \\
\hline$\Theta$ range (deg) & 3.02 to 28.26 & 2.19 to 29.96 \\
\hline index ranges & $-21 \leq \mathrm{h} \leq 21$ & $-20 \leq \mathrm{h} \leq 20$ \\
\hline
\end{tabular}




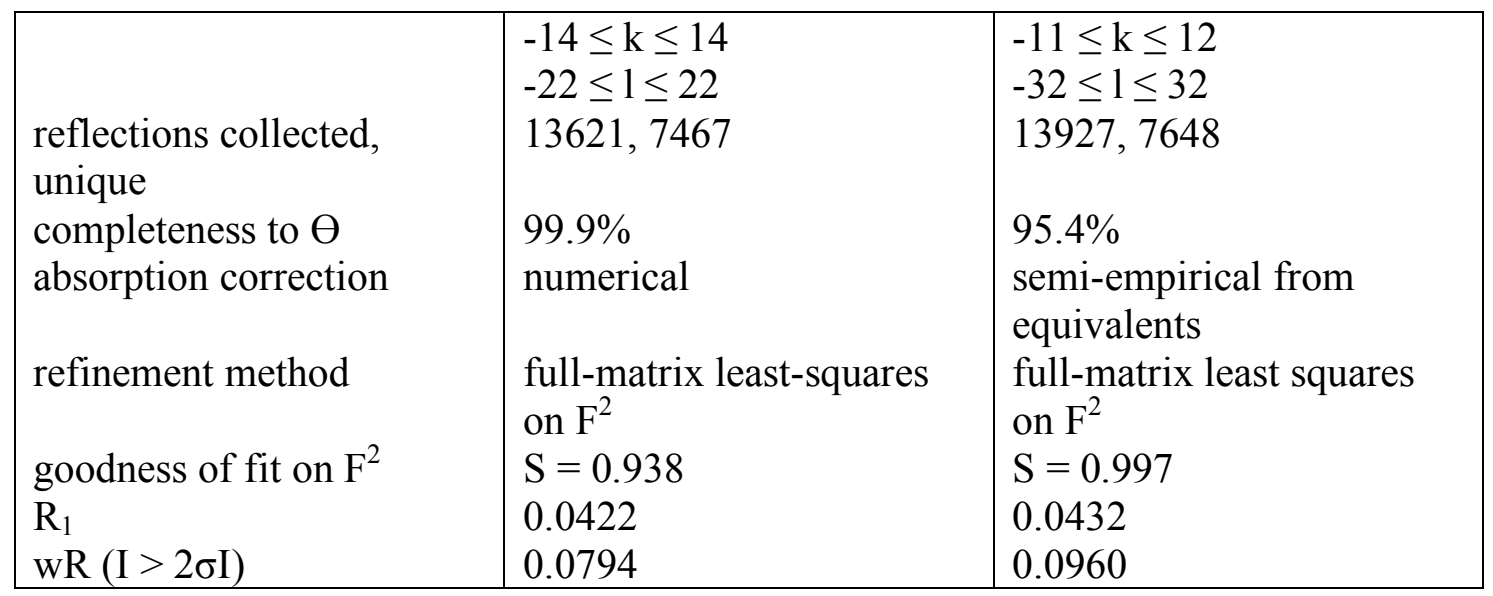

General Considerations. All reactions were carried out under a dry nitrogen atmosphere using standard glove-box and Schlenk techniques. Benzene- $d_{6}$ and cyclohexane- $d_{12}$ were purchased from Cambridge Isotope Laboratories, and dried over sodium/benzophenone. All other chemicals were purchased from Aldrich. 2,6diisopropylaniline was redistilled prior to use, and all other reagents were used as received. THF, pentane, toluene, and benzene were dried by passage through activated alumina and molecular sieve columns. NMR spectra were obtained at room temperature on Bruker AV300 or AV500 MHz spectrometers, with chemical shifts $(\delta)$ reported in ppm downfield of tetramethylsilane. Compounds $\mathbf{1 a},{ }^{1} \mathbf{2 a},{ }^{2}\left[\mathrm{Pt}\left(\mathrm{CH}_{3}\right)_{3} \mathrm{OSO}_{2} \mathrm{CF}_{3}\right]_{4},{ }^{3}$ and HAnIm $^{4}$ were prepared according to published procedures.

KAnIm. HAnIm (Ortho- $\left.\mathrm{C}_{6} \mathrm{H}_{4}\left\{\mathrm{NH}\left(\mathrm{C}_{6} \mathrm{H}_{3}{ }^{\mathrm{i}} \mathrm{Pr}_{2}\right)\right\}\left(\mathrm{CH}=\mathrm{NC}_{6} \mathrm{H}_{3}{ }^{\mathrm{i}} \mathrm{Pr}_{2}\right)\right)(71.3 \mathrm{mg}, 0.162$ $\mathrm{mmol})$ was dissolved in THF $(2.0 \mathrm{~mL})$. Upon addition of $\mathrm{KH}(68.0 \mathrm{mg}, 1.70 \mathrm{mmol})$, hydrogen gas evolved and the pale yellow solution turned a deep red color. The reaction mixture was stirred overnight, then allowed to stand without disturbance for one hour while the KH settled. The deep red solution was carefully transferred off of the $\mathrm{KH}$ and into a glass bomb by pipette. The THF was removed under vacuum to yield a redcolored oil. The red oil was dissolved in toluene and then toluene was removed under vacuum. The resulting red oil was subjected to vacuum overnight. ${ }^{1} \mathrm{H}$ NMR $\left(\mathrm{C}_{6} \mathrm{D}_{6}, 300\right.$ MHz) $\delta 8.13(\mathrm{~s}, 1 \mathrm{H}, \mathrm{N}=\mathrm{CH}), 7.32$ (d, 2H, $J=8.1 \mathrm{~Hz}, \mathrm{Ar}), 7.19(\mathrm{~m}, 5 \mathrm{H}, \mathrm{Ar}), 7.00$ (dt, 1H, $J=6.9,1.8 \mathrm{~Hz}, \mathrm{Ar}), 6.33$ (d, 1H, $J=9.0 \mathrm{~Hz}, \mathrm{Ar}), 6.26$ (t, 1H, $J=7.5 \mathrm{~Hz}, \mathrm{Ar}), 3.50$ (sp, 
$\left.2 \mathrm{H}, J=6.9 \mathrm{~Hz}, \mathrm{CHCH}_{3}\right), 3.22\left(\mathrm{sp}, 2 \mathrm{H}, J=6.9 \mathrm{~Hz}, \mathrm{CHCH}_{3}\right), 1.28(\mathrm{~d}, 6 \mathrm{H}, J=7.2 \mathrm{~Hz}$, $\left.\mathrm{CHCH}_{3}\right), 1.17\left(\mathrm{~d}, 12 \mathrm{H}, J=6.9 \mathrm{~Hz}, \mathrm{CHCH}_{3}\right), 1.13\left(\mathrm{~d}, 6 \mathrm{H}, J=6.6 \mathrm{~Hz}, \mathrm{CHCH}_{3}\right)$.

$(\mathbf{A n I m}) \operatorname{Pt}\left(\mathbf{C H}_{3}\right)_{3} \mathbf{( 1 b )}$. To an orange solution of KAnIm (76.0 mg, $\left.0.159 \mathrm{mmol}\right)$ in benzene $(3 \mathrm{~mL})$ was added white solid $\left[\mathrm{Pt}\left(\mathrm{CH}_{3}\right)_{3} \mathrm{OSO}_{2} \mathrm{CF}_{3}\right]_{4}(61.9 \mathrm{mg}, 0.0398 \mathrm{mmol})$. The reaction mixture turned a deep red color and potassium triflate precipitated. The mixture was stirred for 5 minutes, then filtered through a Teflon syringe filter. The benzene was removed from the filtrate under vacuum, and the resulting red solid recrystallized from pentane at $-35{ }^{\circ} \mathrm{C}$. Yield: $0.0783 \mathrm{~g}(72 \%)$. When protected from light, 1b was stable in solution at room temperature for 2-3 days. The red solid was stored at $35{ }^{\circ} \mathrm{C} . \quad{ }^{1} \mathrm{H}$ NMR $\left(\mathrm{C}_{6} \mathrm{D}_{6}, 300 \mathrm{MHz}\right) \delta 8.28$ (s with ${ }^{195} \mathrm{Pt}$ satellites, $1 \mathrm{H}, J=33.3 \mathrm{~Hz}$, $\mathrm{C}=\mathrm{N} H), 7.34(\mathrm{~d}, 2 \mathrm{H}, J=8.1 \mathrm{~Hz}, \mathrm{Ar}), 7.20(\mathrm{~m}, 4 \mathrm{H}, \mathrm{Ar}), 7.06(\mathrm{dd}, 1 \mathrm{H}, J=7.8,1.5 \mathrm{~Hz}$, Ar), $6.98(\mathrm{~m}, 1 \mathrm{H}, \mathrm{Ar}), 6.57$ (d, 1H, $J=9.3 \mathrm{~Hz}, \mathrm{Ar}), 6.32$ (dd, 1H, $J=7.8,6.6 \mathrm{~Hz}, \mathrm{Ar})$, $3.11\left(\mathrm{sp}, 2 \mathrm{H}, J=7.2 \mathrm{~Hz}, \mathrm{CH}\left(\mathrm{CH}_{3}\right)_{2}, 3.05\left(\mathrm{sp}, 2 \mathrm{H}, J=6.6 \mathrm{~Hz}, \mathrm{CH}\left(\mathrm{CH}_{3}\right)_{2}, 1.24\right.\right.$ (d, 6H, $J=$ $\left.6.9 \mathrm{~Hz}, \mathrm{CH}\left(\mathrm{CH}_{3}\right)_{2}\right), 1.20$ (d, 6H, $\left.J=6.9 \mathrm{~Hz}, \mathrm{CH}\left(\mathrm{CH}_{3}\right)_{2}\right), 1.17$ (d, 6H, $J=6.9 \mathrm{~Hz}$, $\left.\mathrm{CH}\left(\mathrm{CH}_{3}\right)_{2}\right), 1.14$ (s with ${ }^{195} \mathrm{Pt}$ satellites, $\left.9 \mathrm{H}, J=73.8 \mathrm{~Hz},\left(\mathrm{Pt}-\mathrm{CH}_{3}\right)_{3}\right), 1.06(\mathrm{~d}, 6 \mathrm{H}, J=6.9$ $\left.\mathrm{Hz}, \mathrm{CH}\left(\mathrm{CH}_{3}\right)_{2}\right)$. Anal. Calcd for $\mathrm{C}_{34} \mathrm{H}_{48} \mathrm{~N}_{2} \mathrm{Pt}$ : C, 60.07; H, 7.12; N, 4.12. Found: C, 60.45; H, 7.27; N, 4.11.

AnIm Pt(II) Olefin Hydride (2b-h 27$)$. Compound $1 \mathbf{b}(6.2 \mathrm{mg}, 0.0091 \mathrm{mmol})$ was weighed into a resealable Teflon-valve NMR tube and benzene $(0.35 \mathrm{~mL})$ was added by vacuum transfer. The reaction mixture was heated to $150{ }^{\circ} \mathrm{C}$ for 10 minutes, and allowed to cool to room temperature. The solvent was removed under vacuum, yielding a dark brown oil. Complex $2 \mathbf{b}$ was produced in $95 \%$ yield, as judged by ${ }^{1} \mathrm{H}$ NMR integration (when the reaction was conducted in benzene- $d_{6}$ ) against the internal standard 1,3,5-tri-t-butylbenzene. ${ }^{1} \mathrm{H}$ NMR $\left(\mathrm{C}_{6} \mathrm{D}_{6}, 500 \mathrm{MHz}\right) \delta 8.39\left(\mathrm{~d}, 1 \mathrm{H},{ }^{4} \mathrm{~J}=6.5 \mathrm{~Hz}, \mathrm{C}=\mathrm{N} H\right)$, $7.34(\mathrm{dd}, 2 \mathrm{H}, J=12.5,7.5 \mathrm{~Hz}, \mathrm{Ar}), 7.26$ (t, 1H, $J=8.0 \mathrm{~Hz}, \mathrm{Ar}), 7.14$ (m, 1H, Ar), 7.02 (m, 2H, Ar), $6.93(\mathrm{~d}, 1 \mathrm{H}, J=5.5 \mathrm{~Hz}, \mathrm{Ar}), 6.83(\mathrm{t}, 1 \mathrm{H}, J=7.5 \mathrm{~Hz}, \mathrm{Ar}), 6.63$ (d, 1H, $J=$ $9.5 \mathrm{~Hz}, \mathrm{Ar}), 6.41$ (t, $1 \mathrm{H}, J=7.0 \mathrm{~Hz}, \mathrm{Ar}), 3.85$ (m, $\left.1 \mathrm{H}, \mathrm{CH}\left(\mathrm{CH}_{3}\right)_{2}\right), 3.83$ (s with ${ }^{195} \mathrm{Pt}$ satellites, $\left.1 \mathrm{H}, J=69.0 \mathrm{~Hz}, \mathrm{C}\left(\mathrm{CH}_{3}\right)=\mathrm{CHH}\right), 3.64\left(\mathrm{~m}, 1 \mathrm{H}, \mathrm{CH}\left(\mathrm{CH}_{3}\right)_{2}\right), 3.43$ (s with ${ }^{195} \mathrm{Pt}$ satellites, $\left.1 \mathrm{H}, J=71.0 \mathrm{~Hz}, \mathrm{C}\left(\mathrm{CH}_{3}\right)=\mathrm{CHH}\right), 3.04\left(\mathrm{~m}, 1 \mathrm{H}, \mathrm{CH}\left(\mathrm{CH}_{3}\right)_{2}\right), 2.14$ (s with ${ }^{195} \mathrm{Pt}$ satellites, $\left.3 \mathrm{H}, J=33.5 \mathrm{~Hz}, \mathrm{C}\left(\mathrm{CH}_{3}\right)=\mathrm{CH}_{2}\right), 1.50\left(\mathrm{~d}, 3 \mathrm{H}, J=9.0 \mathrm{~Hz}, \mathrm{CH}\left(\mathrm{CH}_{3}\right)_{2}\right), 1.42$ (d, $\left.3 \mathrm{H}, J=7.0 \mathrm{~Hz}, \mathrm{CH}\left(\mathrm{CH}_{3}\right)_{2}\right), 1.26\left(\mathrm{~d}, 3 \mathrm{H}, J=6.0 \mathrm{~Hz}, \mathrm{CH}\left(\mathrm{CH}_{3}\right)_{2}\right), 1.21(\mathrm{~d}, 3 \mathrm{H}, J=9.0 \mathrm{~Hz}$, 
$\left.\mathrm{CH}\left(\mathrm{CH}_{3}\right)_{2}\right), 1.18\left(\mathrm{~d}, 3 \mathrm{H}, J=5.5 \mathrm{~Hz}, \mathrm{CH}\left(\mathrm{CH}_{3}\right)_{2}\right), 0.83\left(\mathrm{~d}, 3 \mathrm{H}, J=6.0 \mathrm{~Hz}, \mathrm{CH}\left(\mathrm{CH}_{3}\right)_{2}\right)$, 16.93 (d (due to coupling with imine C- $H$ ) with ${ }^{195} \mathrm{Pt}$ satellites, $1 \mathrm{H}, J=1254.1,6.0 \mathrm{~Hz}$, $\mathrm{Pt}-H$ ). ${ }^{13} \mathrm{C}\left\{{ }^{1} \mathrm{H}\right\}\left(50 \mathrm{MHz}\right.$, benzene- $\left.d_{6}\right) \delta 158.81$ (s), 156.26 (s with ${ }^{195} \mathrm{Pt}$ satellites, $J=$ $24.0 \mathrm{~Hz}$ ), 150.86 (s), 149.84 (s with ${ }^{195} \mathrm{Pt}$ satellites, $J=31.0 \mathrm{~Hz}$ ), 145.30 (s), 144.07 (s with ${ }^{195} \mathrm{Pt}$ satellites, $J=20.2 \mathrm{~Hz}$ ), 141.55 (s), 141.39 (s), 136.93 (s), 134.81 (s), 128.92 (s)*, 126.35 (s), $125.78(\mathrm{~s}), 124.76$ (s), 124.21 (s), 119.57 (s with ${ }^{195} \mathrm{Pt}$ satellites, $J=53.0$ $\mathrm{Hz}$ ), 116.58 (s with ${ }^{195} \mathrm{Pt}$ satellites, $J=34.0 \mathrm{~Hz}$ ), 115.13 (s), 92.15 (s with ${ }^{195} \mathrm{Pt}$ satellites, $J=204.2 \mathrm{~Hz}$ ), 61.49 (s with ${ }^{195} \mathrm{Pt}$ satellites, $J=147.7 \mathrm{~Hz}$ ), 30.57 (s), 29.05 (s), 28.43 (s), 28.25 (s), $25.72(\mathrm{~s}), 25.05$ (s), $24.87(2 \mathrm{C}, \mathrm{s}) *, 24.40$ (s), 23.99 (s). *The chemical shift of the carbon signal at $128.92 \mathrm{ppm}$, which lies underneath the benzene solvent signal, was verified by an HMQC experiment. This experiment also indicated that the resonance at 24.87 ppm corresponds to 2 carbon nuclei.

General Procedure for Kinetic Runs. In the drybox, 1a or $\mathbf{1 b}$ (ca. $5 \mathrm{mg}$ ) and mesitylene or 1,3,5-tri-tert-butylbenzene (internal standard) were dissolved in benzene- $d_{6}$ $(0.30 \mathrm{~mL})$. The solution was added to a medium-walled NMR tube fitted to a vacuum adaptor, and the tube was flame sealed under vacuum. NMR tubes were heated in a steel jacket in a Neslab Exacal EX-250 HT oil bath at $60{ }^{\circ} \mathrm{C}$, and the reaction quenched at interval times by cooling in ice water. The samples were followed for 3 half-lives (ca. 10 data points), and the rate constants calculated from the average of three runs. At late reaction times for compound 1a, a small shoulder appeared on the mesitylene methyl signal, indicating that some deuterium incorporation had occurred into the mesitylene standard. However, the rate agreed with the rate measured using the sterically hindered 1,3,5-tri-tert-butylbenzene as an internal standard. In addition, the plot of $\ln [\mathbf{1} \mathbf{a}]$ vs $t$ was linear, and the rate calculated from the first four data points agreed with the rate calculated from all of the data points within error, demonstrating that this minor deuterium incorporation did not significantly impact the analysis. 


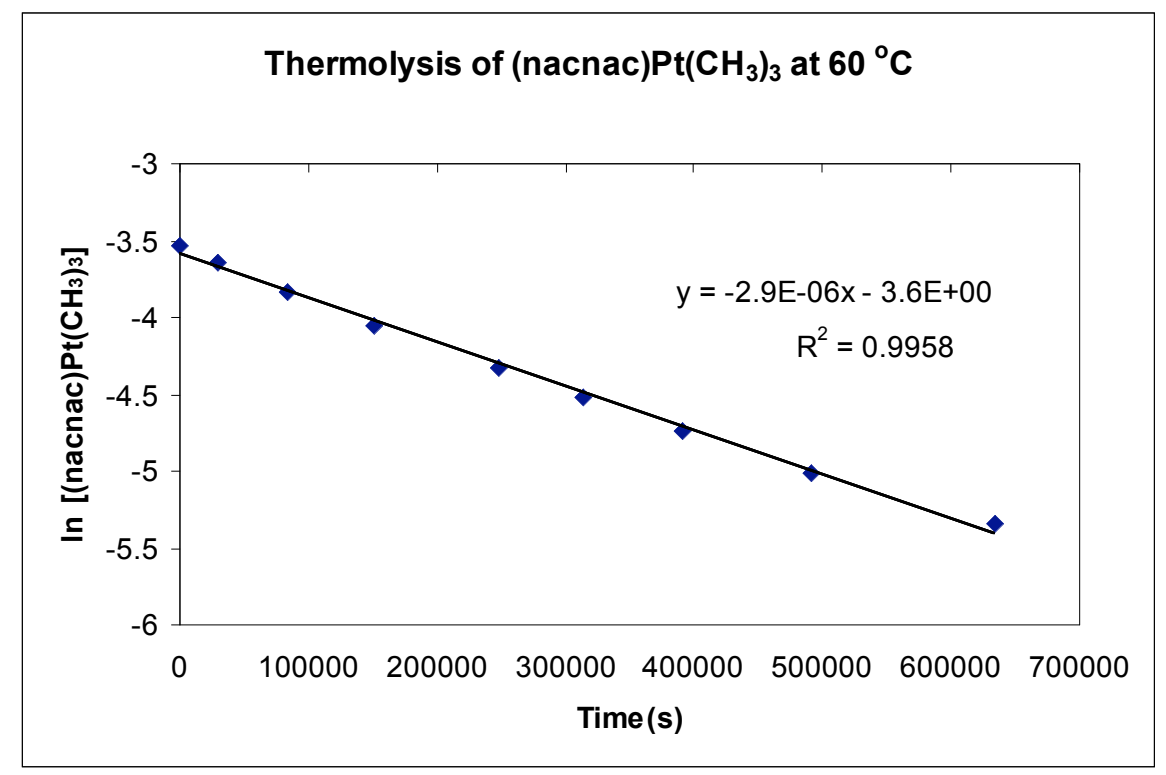

Figure S2. Kinetic Plot of the Thermolysis of (nacnac) $P t\left(C_{3}\right)_{3}(1 a)$

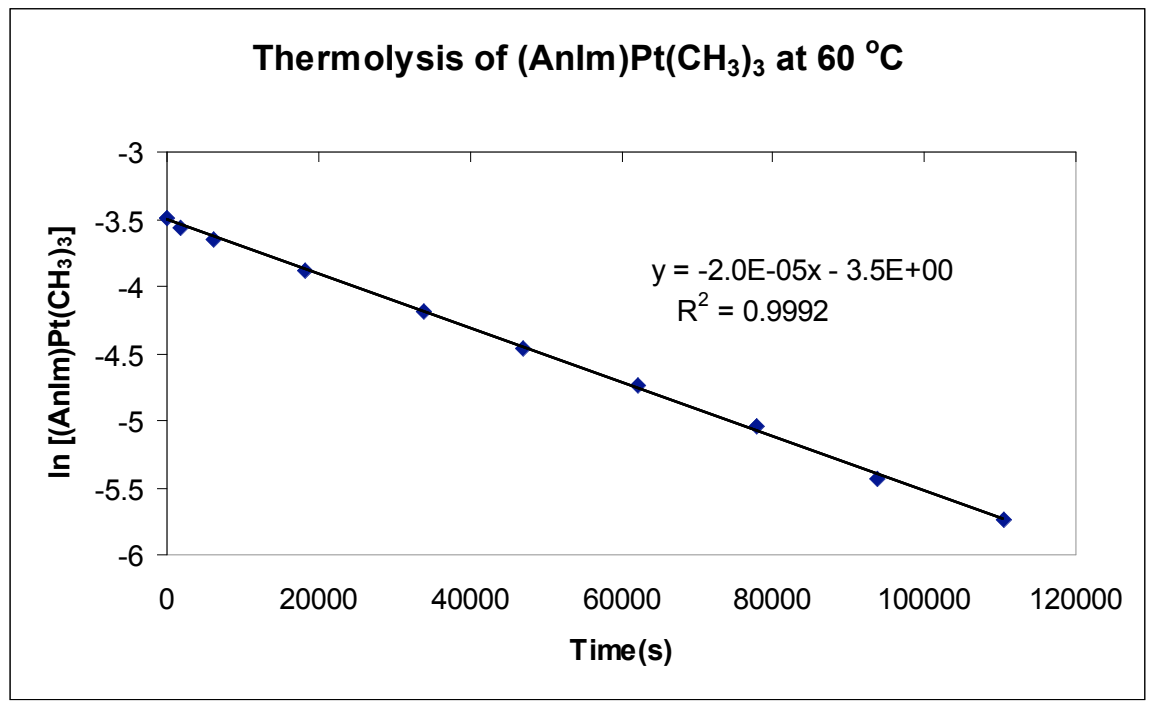

Figure S3. Kinetic Plot of the Thermolysis of $(\mathrm{AnIm}) \operatorname{Pt}\left(\mathrm{CH}_{3}\right)_{3}(1 \mathrm{~b})$

Observation of the cis-Imine-hydride AnIm Pt(II) Olefin Hydride Complex (cis-2b)

When the thermolysis of $\mathbf{1 b}$ was conducted in benzene at $60{ }^{\circ} \mathrm{C}$ for $13 \mathrm{~h}$, stopped prior to completion, and the reaction mixture examined by ${ }^{1} \mathrm{H}$ NMR (benzene- $d_{6}$ ), characteristic resonances attributed to the isomer of the AnIm Pt(II) olefin hydride complex having the imine and hydride groups cis to one another (cis-2b) could be assigned, along with resonances corresponding to trans-2b, the only olefin hydride 
product observed upon reaction completion. During the kinetic runs, when the thermolysis of $\mathbf{1 b}$ was followed in benzene- $d_{6}$, $\boldsymbol{c i s}-\mathbf{2} \mathbf{b}-\boldsymbol{d}_{\mathbf{2}}$ was observed as a kinetic product of the reaction along with the thermodynamic product trans-2b- $\boldsymbol{d}_{\mathbf{2 7}}$. The yield of the cis isomer $\boldsymbol{c i s}-\mathbf{2} \mathbf{b}-\boldsymbol{d}_{\mathbf{2}}$ reached a maximum of $40 \%$ of the observed products at $60 \%$ conversion (after heating in benzene- $d_{6}$ at $60{ }^{\circ} \mathrm{C}$ for $\left.13 \mathrm{~h}\right) .{ }^{1} \mathrm{H}$ NMR for $\boldsymbol{c i s}-\mathbf{2 b}\left(\mathrm{C}_{6} \mathrm{D}_{6}, 300\right.$ MHz) $\delta 7.49(\mathrm{~s}, 1 \mathrm{H}, \mathrm{C}=\mathrm{N} H), 1.92$ (s with ${ }^{195} \mathrm{Pt}$ satellites, $3 \mathrm{H}, J=28.2 \mathrm{~Hz}, \mathrm{C}\left(\mathrm{CH}_{3}\right)=\mathrm{CH}_{2}$ ), -17.59 (s with ${ }^{195} \mathrm{Pt}$ satellites, $1 \mathrm{H},{ }^{2} J_{\mathrm{Pt}-\mathrm{H}}=1006.9 \mathrm{~Hz}, \mathrm{Pt}-H$ ).

\section{General Procedure for the Deuterium Exchange Experiments}

In the drybox, a resealable teflon-capped NMR tube was charged with $\mathbf{2 a}$ or $\mathbf{2 b}$ (ca. $5 \mathrm{mg}$ ) and solid 1,3,5-tri-tert-butylbenzene (internal standard). Benzene- $d_{6}(0.30$ $\mathrm{mL}$ ) was added, the reaction was heated at $60^{\circ} \mathrm{C}$ or $130{ }^{\circ} \mathrm{C}$, and followed by ${ }^{1} \mathrm{H} N M R$. The extent of deuterium incorporation into the ligand isopropyl, olefinic, and hydride positions was determined by comparison of the integrals of these peaks against the $\gamma \mathrm{C}-H$ peak of $\mathbf{2 a}(4.95 \mathrm{ppm})$ or the imine C- $H$ peak of $\mathbf{2} \mathbf{b}(8.39 \mathrm{ppm})$, which did not incorporate deuterium. Integration against the internal standard revealed that no significant decomposition of the olefin hydride complexes occurred under these conditions.

\section{Deuterium Exchange into $n$-Pentane}

To a resealable teflon-capped NMR tube containing $\mathbf{2} \mathbf{b}-\boldsymbol{d}_{27}(3.5 \mathrm{mg}, 0.0053$ mmol), was added $n$-pentane $(0.35 \mathrm{~mL})$ by vacuum transfer. The tube was heated at 130 ${ }^{\circ} \mathrm{C}$ for $48 \mathrm{~h}$. The reaction was cooled to room temperature and the pentane was vacuum transferred into a separate tube. The ${ }^{2} \mathrm{H}$ NMR spectrum of the pentane solvent revealed that deuterium had incorporated into the terminal position with about $87 \%$ selectivity (Figure S4). 


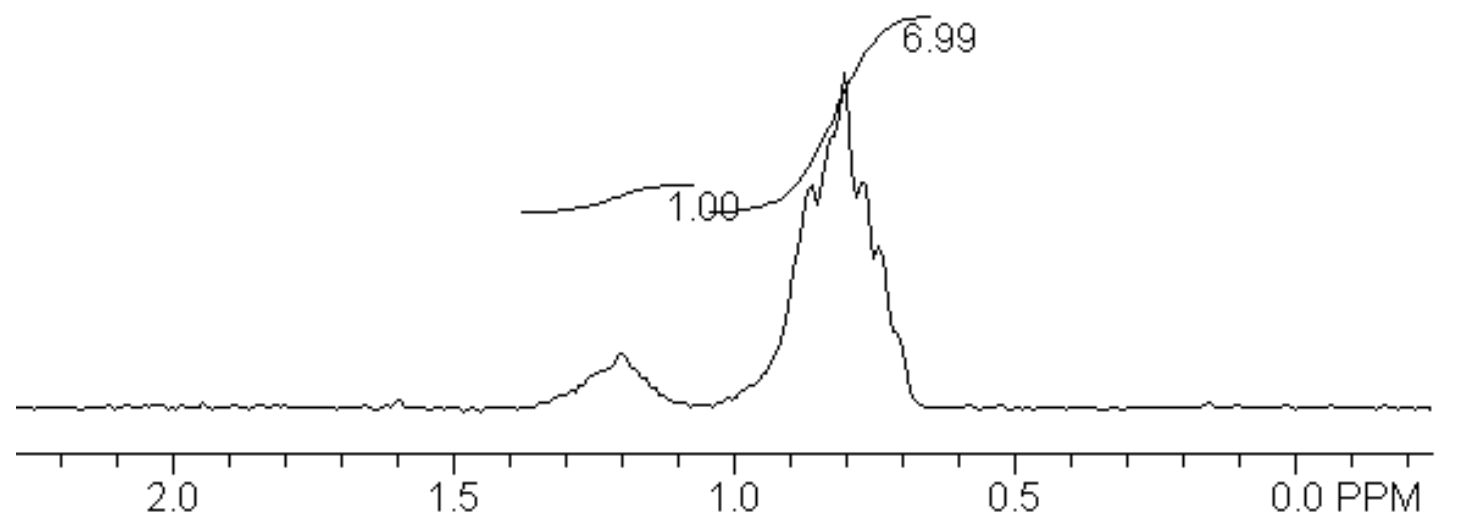

Figure S4. ${ }^{2}$ H NMR Spectrum of $n$-Pentane From the Exchange Reaction. Comparison of the integrals of the terminal and secondary positions indicates that deuterium incorporation into the terminal position was favored over the statistical (1:1) ratio by a factor of about 7 .

\footnotetext{
${ }^{1}$ Fekl, U.; Kaminsky, W.; Goldberg, K. I. J. Am. Chem. Soc. 2001, 123, 6423.

${ }^{2}$ Fekl, U.; Goldberg, K. I. J. Am. Chem. Soc. 2002, 124, 6804.

${ }^{3}$ Schlecht, S.; Magull, J.; Fenske, D.; Dehnicke, K. Angew. Chem. Int. Ed. 1997, 36, (18), 1994.

${ }^{4}$ Hayes, P. G.; Welch, G. C.; Emslie, D. J. H.; Noack, C. L.; Piers, W. E.; Parvez, M. Organometallics 2003, 22, 1577.
} 